\title{
Promotion of Producer Contribution to Solve Packaging Waste Issues - Viewpoints of Waste Bank Members in the Bandung Area, Indonesia
}

Antonius Priyo Nugroho Sulami ( $D$ a_priyon@yahoo.com )

Tokyo Institute of Technology: Tokyo Kogyo Daigaku https://orcid.org/0000-0003-3487-6046

Takehiko Murayama

Tokyo Institute of Technology: Tokyo Kogyo Daigaku

Shigeo Nishikizawa

Tokyo Institute of Technology: Tokyo Kogyo Daigaku

\section{Research}

Keywords: Packaging waste, waste bank, extended producer responsibility, producer, waste management

Posted Date: June 17th, 2021

DOI: https://doi.org/10.21203/rs.3.rs-600913/v1

License: (1) This work is licensed under a Creative Commons Attribution 4.0 International License.

Read Full License 


\section{Abstract}

As regulations have developed, the waste management sector in Indonesia has increasingly expected producer involvement in waste reduction activity through the enactment of new regulations. In addition, recent development of the waste management sector now involves community-based approaches such as Waste Banks. This study aims to determine the relationship between extended producer responsibility implementation and the waste bank concept. A questionnaire survey was designed and applied to Waste Bank members of two Waste Banks in Bandung municipality, Indonesia. Several factors were identified that can be considered by producers to promote their contribution in dealing with the packaging waste issue, such as producer consideration and contribution, knowledge level, collection, and awareness of the importance of packaging waste issue. The result also shows that involving feedback from Waste Banks can provide some insights to expand and develop producer contribution in reducing the impact of packaging waste. Producers can improve collection and recyclability of their product packaging while increasing public knowledge on their activity at the post-consumer stage.

\section{Introduction}

The development of waste management policy in Indonesia has already considered the role of the producer in reducing their impact on waste management, starting with the implementation of Law no. 18 year 2008 on Waste Management [22]. The producer's role in waste management was also reinforced by subsequent government or ministry regulations such as Government Regulation of Republic of Indonesia no. 81 year 2012 on Domestic Waste Management and similar waste and the Ministry of Environment Regulation no. 13 year 2012 about Implementation of Reduce, Reuse, Recycle (3R) through Waste Bank [22]. In the latter regulation, the appendix of the regulation mentions the integration of the waste bank concept with the extended producer responsibility (EPR) concept [14]. The Government Regulation of Republic of Indonesia no. 81 year 2012 defines producers as businesses that produce, distribute, and sell goods and uses packaging or containers that does not or are difficult to naturally degrade [7].

Waste Bank is a campaign to address the waste problem by buying back and recovering money from waste using a banking system [16]. In the waste bank system, pre-sorted waste is collected and monetarily valued. The member who submits the pre-sorted waste may save the money from the valuation activity into an account, just like a banking system. The waste bank often cooperates with recyclers to exchange the collected waste for money. In some cities in Indonesia, such as Makassar, community-based waste banks are reinforced by the establishment of a central waste bank to gain leverage in terms of quantity and added value of waste [10].

EPR is a policy approach that aims to extend the responsibility of producers to also include the postconsumer stage of the products [15]. According to Organization for Economic Co-operation and Development (OECD), approximately 384 cases of the EPR system have been adopted so far globally and practiced in various forms [15]. The most common EPR strategies include the adoption of take-back activity, deposit-refund scheme, environmental-friendly design, and EPR policy, which helps to reduce the 
financial burden of waste on municipalities, decrease the amount of waste in final disposal, and increase the recycling rate [15].

However, adoption of the EPR concept as a policy needs careful consideration of the existing waste management system or post-consumer stage. In developing countries, adoption of EPR policy similar to in developed country faces several challenges, such as improper waste management or differences in the roles of stakeholders [1], and the existence of an informal recycling sector [8]. However, there is also evidence that carefully considering the role of key stakeholders in developing EPR policy may create a different approach of EPR policy adoption, as seen in Colombia where a shared responsibility approach is adopted between government institutions, private sectors, the informal recycling sector, and other stakeholders [15]. Marshall and Farahbakhsh [12] also highlighted the importance of a suitable strategy for waste management in the context of developing countries.

According to the OECD [15], fast economic growth in developing countries may increase the demand of newer and more variation of goods from the middle-income class, which leads to a more complex stream of waste in the post-consumer stage. The more complex stream of waste may have negatively impact environmental and public health when not treated properly. Therefore, improvement of the waste management system is required to manage new challenges from more complex waste streams.

Indonesia is subject to some of the abovementioned challenges, and the informal recycling sector plays an important role [4]. In a recent study by Putri et al. [17] on plastic waste recycling, the informal recycling sector collected approximately $33.8 \%$ of plastic waste generated in Jakarta, compared to $0.39 \%$ collected by the waste bank system, and $54.3 \%$ of plastic waste goes to final disposal sites. These studies show the reliance on the final disposal site for waste management in Indonesia; meanwhile, the informal recycling sector still plays a major role in recycling in Indonesia. Although they exist, alternative approaches to recycling, such as Waste Banks, still account for a small portion of waste management due to reliance to consumer participation [17].

Several past studies have investigated the role of waste banks in waste management, such as those by Raharjo et al. [18] in Padang city and Kubota et al. [10] in Makassar city, which focused more on how waste banks can support existing waste management systems. Although conducted in different areas, both studies suggest the integration of the Waste Bank system with the formal waste management system run by the local government/public sector. A study by Wijayanti and Suryani [26] in Surabaya demonstrated that wide adoption of Waste Banks successfully reduces the amount of waste to local final disposal sites. In addition, Waste Banks have positive economic, social, educational, and governance impacts in the community [26].

Considering the main findings in major cities in Indonesia, this study considers Waste Banks as a sourceseparated post-consumer waste route, and community-based approaches may provide relevant insight in 
Indonesia, especially in the early post-consumer stage. Waste Banks were selected as the focus for two reasons:

1. Waste banks, as a community-based approach, promote direct behavioral impacts on waste management.

Considering the mechanism of Waste Banks, members must sort waste at the source before it can be submitted and traded to generate financial savings. As stated by Leal Filho et al. [11], source separation and sorting are imperative to improve the recycling rate.

2. Waste banks collect directly from a group of households.

Compared to the traditional informal sector, Waste Banks rely on the clients' participation [17]. Therefore, Waste Banks usually only accept and collect waste from member households. As the scale may vary, the possibility to simultaneously collect waste from several households means that Waste Banks can collect a considerable amount of waste. If the waste bank is scaled up appropriately, they can obtain leverage in terms of quantity. This may provide a better level of traceability compared to the traditional informal recycling sector, which is necessary for the producer sector to ensure that post-consumer products are treated responsibly. Traceability is considered as an important factor by Tong et al. [24].

Packaging waste was selected as the focus in this study following a common practice observation of Waste Banks in Indonesia which focus on collecting separated packaging waste from households that still has economic value when traded with the informal recycling sector. A categorization system from Waste4Change [25] provides typical types of packaging that are also commonly collected at Waste Banks. Furthermore, several established EPR schemes focus on packaging waste; therefore, it is easier to find examples of packaging waste EPR practices.

Several previous studies have focused on factors contributing to participation in waste management programs. Suttibak and Nitivattananon [23] highlighted the enhancement of perception of awareness, operator skill, source separation, and transportation cost in Thailand. Khan et al. [9] and Stoeva and Alriksson [21] used the theory of planned behavior in their study framework and highlighted the importance of convenient collection as well as awareness of recycling benefit.

The abovementioned studies discussed the role of the general informal sector in waste management and its implication on the formulation of EPR policy. However, this study focuses on the feedback of Waste Banks, a community-based approach, to recommend policy for EPR implementation. The objective of this study is to clarify the viewpoints of waste bank members on producer contribution in the post-consumer stage for packaging waste, while considering the Waste Bank role.

Considering the abovementioned challenges of implementing EPR in developing countries using the definition of developed countries, this study interpreted EPR differently. Indonesian regulations rarely use "EPR," instead implying producers must reduce the impact generated by their products. To reflect such conditions in this study, EPR is generally interpreted as the contribution of producers to reduce the impact 
of products at the post-consumer stage and refers to producer contribution in the general EPR conception.

\section{Material And Methods}

\subsection{Questionnaire Design}

Input feedback from Waste Bank members was collected to address the research objective considered because waste banks have already improved member's awareness and behavior toward source separation.

Feedback obtained from Waste Banks was quantitatively analyzed to determine the areas which require improvement and how the producer sector can contribute. A questionnaire survey was prepared to collect necessary information. The answer format included Likert scale, multiple choice, or open-ended responses. A total of 34 questions were prepared and divided into 4 groups as follows:

\section{General information}

In this group, questions based on location and length of residency, age, and occupation were asked to obtain demographic information. For residency, respondents were required to state whether they are living inside Bandung area or not. Respondents were required to state approximate years of residency and age. For occupation, respondents were required to pick one of the provided options of occupation.

\section{Waste Bank activity and environmental impact at post-consumer stage}

This group consisted of 10 questions, with the main purpose of asking about the impact of waste bank membership on their awareness and behavior toward packaging waste. In addition, a sub-group of questions asked about the respondents' knowledge regarding the EPR concept or any program from producers or brand owners to reduce the impact of their packaging. For waste bank membership, respondents were required to choose whether they have joined waste bank less or more than 1 year. For questions related to awareness, behavior change, and importance of packaging waste issue, respondents could pick one answer from Yes/No/Don't know choices. Respondents could pick multiple choices for questions related to treatment of waste not submitted to waste bank, packaging difficult to recycle, and source of knowledge. For questions related to knowledge level of EPR concept and producer program, respondents were required to pick one from 4 Likert scale.

\section{Evaluation of role of incentive mechanism}

This group comprised seven questions to assess the importance of the incentive mechanism in waste banks to their willingness to participate and how it changes their packaging preferences. Respondents were required to pick one of 5 Likert scale for questions related to importance of incentive mechansim, influence of waste price, and importance of waste bank role. For questions related to willingness and 
consideration of packaging, respondents could pick one from Yes/No/Don't know choices. For encouragement factor and packaging that is avoided, respondents were allowed to pick multiple choices.

\section{Improvement of producer contribution at the post-consumer stage}

This group consisted of 13 questions focusing on how producer contribution in the post-consumer stage can be improved. Respondents were required to pick one of 5 Likert scale for questions related to EPR aspects of producer contribution, consideration of recyclability, collection, involvement of waste bank, feedback collection, producer aid, and transparency. Respondents were allowed to make multiple choice on questions related to contribution issue and options for waste bank involvement. For questions related to important stakeholders, respondents could pick one from several choices.

As there were no clearly defined categories in Indonesia for packaging waste, this study used categorization from Waste4Change, a local waste management company that collaborated with a local producer initiative to provide collection points around Jakarta [25].

Figure 1 shows the interrelationship between each question group and how the data was analyzed. Questions from "Waste Bank activity and environmental impact at post-consumer stage" and "Evaluation of the role of the incentive mechanism" were used to determine producer contribution improvement considering the respondents' perspectives.

\subsection{Data Collection and Analysis}

The questionnaire was targeted at members of active Waste Banks located in the Bandung municipality area. The sample was collected by directly asking the participants, assisted by a team of surveyors to fill in the questionnaire sheet. In total, 126 responses were collected in August 2019 from two Waste Banks; one within and one outside of Bandung municipality area, but served by the Bandung municipality Cleaning Agency. The response rates were $38.85 \%$ for Waste Bank inside Bandung and $29.07 \%$ for Waste Bank outside Bandung, reflecting the percentage of waste bank members that participated in the survey compared to the total number of waste bank members in the respective waste banks. The approximate location of the waste banks is shown in Figure 2.

Bandung municipality is the capital of West Java Province, Indonesia, with a population of $2,470,802$ people by the end of 2014 [2]. Several previous studies investigated waste management in the area [3-4, 19]. The availability of past studies in the area is one of the main reasons why Bandung municipality area was selected for this study.

The collected data were analyzed using quantitative analysis in SPSS to determine the correlation between selected questions. Factor analysis was then conducted to determine important producer contribution factors in reducing the packaging waste impact.

\section{Results}




\subsection{General Profile}

Approximately $77 \%$ of respondents lived around Bandung municipality, while $19 \%$ lived outside Bandung municipality area. The following is the respondents living duration around the Waste Bank location: 0-9 years (13\%), $10-19$ years (12\%), 20-29 years (37\%), 30-39 years (34\%), 40-49 years $(2 \%), 50-59$ years ( $1 \%$ ). The respondents also came from various age group, which can be described as follows: $20-29(2 \%), 30-$ 39 (13\%), 40-49 (14\%), 50-59 (33\%),60-69 (33\%),70-79 (4\%), and 80-89 (1\%). The varying occupation of respondents can be described as follows: houseviwes $(47 \%)$, retired $(23 \%)$, self-employed ( $8 \%)$, private sector (4\%), and government sector (2\%).

\subsection{Waste Bank Activity and Environmental Impact at Post-consumer Stage}

The questionnaire demonstrated that $87 \%$ and $13 \%$ of respondents had been members of a Waste Bank

for $\geq 1 \mathrm{y}$ and $<1 \mathrm{y}$, respectively. The most common reason for joining Waste Banks was environmental awareness, followed by convenience and financial incentives. Most respondents responded positively to the impact of Waste Bank membership on their awareness (99\%) and behavior toward waste management (97\%), and most respondents perceived packaging waste as an important issue (95\%). Packaging waste that is not submitted to waste banks usually goes to final disposal. Most respondents selected sachet/refill packaging as difficult to recycle (67 responses).

Most respondents were unaware of the EPR concept or producer program to reduce waste impact (63\% and $56 \%$ respectively). Those with knowledge obtained information from the news ( 26 responses) or socialization (23 responses). This shows that there is low level of knowledge within Waste Bank members regarding producer contribution to reduce the impact in the post-consumer stage.

\subsection{Evaluation of Role of Incentive Mechanism}

Most respondents (77\%) perceived the financial mechanism as either "very important" or "important" (Fig. $3)$. However, several were "not so influenced" (20.6\%) or "not influenced at all" (27\%) by packaging waste price, compared to those who were "highly influenced" (10.3\%) or "influenced" (24.6\%) by the same metric. Most respondents were willing to continue participating in Waste Banks even without incentive (96\%). "Environmental Awareness" followed by "Convenience" were the main reasons for this response.

Waste banks are also strongly perceived as having an important role in packaging waste management (96\%). Respondents also demonstrated their packaging avoidance, with "sachet/refill packaging" as the dominant avoided packaging type. This correlates with the question concerning packaging waste that is difficult to recycle in the previous section.

\subsection{Improvement of Producer Contribution at Post-consumer Stage}

The results suggested that members of Waste Banks supported the improvement of producers' physical (95\%), financial (87\%), and organizational (83\%) contribution at the post-consumer stage. "Recyclable material" (89 responses) and "provision of facility" (89 responses) were the most frequent recyclability 
issues. This shows that issues regarding recyclability of packaging material and facility provision have already become a concern in Waste Bank communities. Many respondents supported producers considering the recyclability of their packaging material (95.2\%) and a collection program for packaging waste that is difficult to recycle $(92.1 \%)$. The results also indicate strong support for producers to be involved with Waste Banks (93.7\%), collect feedback from Waste Banks (88.9\%), and help contribute to Waste Bank activity in their contribution (94.4\%). Involvement with Waste Banks can achieved be through socialization (108 responses), collection of packaging waste (45 responses), or other means. The local government is still perceived as an important stakeholder in promoting cooperation with Waste Banks and sharing feedback. Public transparency regarding packaging waste management is also supported (90.5\%).

The results strongly support producers contributing to packaging waste management. The results show there is concern regarding the recyclability of packaging material. One implication of adopting EPR policy in the post-consumer stage is that it can promote the adoption of the Design for the Environment concept, where the producer considers how to reduce their products' environmental impact by promoting design toward recyclability instead of final disposal.

\subsection{Correlation analysis}

Figure 4 shows a relationship diagram based on bivariate analysis of several questions concerning Waste Bank member perceptions. The importance of the packaging waste issue (Question 11) had the most correlation relationships with variables concerning the improvement of producer contribution at the post-consumer stage, followed by EPR knowledge (Question 12) and knowledge of the producer program (Question 13). From "Evaluation of the role of the incentive mechanism," "Importance of waste bank" (Question 19) had the most correlation relationships.

\subsection{Factor Analysis}

Table 1 shows the rotated component score results on variables with strong correlation results based on bivariate analysis. Five components were extracted and grouped.

Table 1 Rotated Component Matrix Result 
Component

\begin{tabular}{llllll} 
& 1 & 2 & 3 & 4 & 5 \\
\hline Q28_wastebank_involvement & 0.841 & 0.099 & 0.161 & -0.096 & 0.222 \\
\hline Q29_feedback_collection & 0.699 & 0.254 & 0.124 & -0.036 & 0.308 \\
\hline Q26_recyclability_consideration & 0.658 & -0.178 & -0.041 & 0.396 & 0.009 \\
\hline Q24_organization_contribution & 0.574 & 0.452 & 0.051 & -0.039 & -0.024 \\
\hline Q31_producer_aid & 0.511 & 0.429 & 0.011 & 0.127 & -0.484 \\
\hline Q22_physical_contribution & 0.080 & 0.834 & 0.156 & -0.042 & -0.033 \\
\hline Q23_Financial_contribution & 0.117 & 0.637 & 0.117 & 0.366 & -0.094 \\
\hline Q34_public_transparency & 0.158 & 0.592 & -0.048 & -0.015 & 0.563 \\
\hline Q12_EPR_knowledge & 0.082 & 0.087 & 0.856 & -0.016 & 0.080 \\
\hline Q13_Program_knowledge & 0.084 & 0.096 & 0.846 & 0.034 & -0.009 \\
\hline Q19_wastebank_role & -0.001 & -0.043 & 0.020 & 0.842 & -0.091 \\
\hline Q27_collection_consideration & 0.029 & 0.340 & -0.018 & 0.634 & 0.278 \\
\hline Q11_importance & 0.335 & -0.106 & 0.104 & 0.095 & 0.685 \\
\hline Eigen value & 2.392 & 2.091 & 1.546 & 1.444 & 1.268
\end{tabular}

Extraction Method: Principal Component Analysis.

Rotation Method: Varimax with Kaiser Normalization.

a. Rotation converged in 8 iterations.

Component 1 was related to activities that producers can consider in response to the packaging waste issue. Therefore, it was labeled as "producer consideration." Component 2 consisted of variables related to the contribution of producers and was labeled as "producer contribution." Component 3 was related to the respondent's knowledge of the EPR concept and program from producers; therefore, it was labeled as "knowledge." Component 4 was related to the perception of the role of Waste Banks and consideration for collection of packaging waste; therefore, it was labeled as "collection cooperation." Component 5 consisted of variables related to awareness regarding the importance of packaging waste issues and how it is managed; therefore, it was labeled as "importance awareness."

When the regression factor value was averaged and grouped by residency duration, a pattern was observed as shown in Figure 5. In terms of producer consideration and producer contribution factor, respondents outside Bandung have a more positive average regression value than respondents located inside Bandung. Respondents outside Bandung also have a more positive average regression value on importance awareness and collection cooperation factors than respondents inside Bandung. 
Respondents outside Bandung have a more negative value for the knowledge factor than respondents inside Bandung. Respondents residing in Bandung $>30 \mathrm{y}$ tend to have more positive average regression values on the producer consideration factor than people residing in the area $<30 \mathrm{y}$. However, respondents residing in the area $<30 \mathrm{y}$ tend to have more positive regression value on producer contribution, knowledge, collection cooperation, and importance awareness factors.

Younger respondents ( $0-34$ y and 35-69 y) tended to have a more positive producer consideration regression value than older respondents (>70 y) (Fig. 6). The oldest age group's regression value was more negative than the younger age group in knowledge and importance awareness factors, but more positive in producer contribution and collection cooperation factors.

Younger respondents ( $0-34$ y and 35-69 y) tended to have a more positive producer consideration regression value than older respondents (>70 y) (Fig. 6). The oldest age group's regression value was more negative than the younger age group in knowledge and importance awareness factors, but more positive in producer contribution and collection cooperation factors.

\section{Discussion}

This study focused on viewpoints on producer contribution from a community-based waste bank approach on reducing packaging waste impacts at the post-consumer stage. that the results show that waste bank members have high awareness and support behavioral changes in waste management. Waste bank members also show the importance of incentive mechanisms in waste bank systems. Waste bank members also show high willingness to participate due to environmental awareness. However, waste bank members show low level of knowledge of the EPR concept and producer program and their reliance on socialization and news to develop knowledge level in this area. Waste bank members also show low levels of influence of waste price at waste banks.

These results indicate that waste bank members have developed a high level of awareness on waste management. Mechanisms that generate incentives for waste bank members to sustain a certain level of awareness and waste management behavior are important. Members collect waste to be traded with recycling sector which generates financial resources that are distributed among members as savings. This constant mechanism may contribute to the high level of awareness and behavior among waste bank members.

Regarding aspects related to producer contribution, waste bank members strongly support the promotion of producer contribution and consideration in packaging issues, which include the scope of EPR concepts, collection cooperation, recyclability, transparency, and aid for waste banks for collection. Waste bank members also regarded the importance of the role of local government agencies and producers in solving packaging waste issues.

Different location of residency may also contribute to the differences of viewpoints for identified components among waste bank members as local waste banks may have 
different supporting institutions. Considering that waste bank members rely on socialization and news, institutions that support waste bank operation may have a role in shaping waste bank members' viewpoints on producer contribution in solving packaging waste issues. Most respondents located outside Bandung join Waste Banks that are mainly supported by the local municipality agency related to waste management, while most respondents located inside Bandung joined Waste Banks managed by the community which are assisted by an NGO and producer program. This factor may affect the respondents' perception of producer involvement in managing packaging waste issues. Since most respondents located outside Bandung are more familiar with activity supported by a local waste management agency, they may perceive producer contribution as more necessary than the other group who are more familiar with support from NGOs and producer programs.

Different age groups also expressed different viewpoints indicating different levels of accumulated knowledge and information related to packaging waste issue. Thus, considering the age demographic can be useful in activity to raise awareness and collective knowledge. This can be seen as a paradigm shift where the younger generation expects a more proactive approach from producers in dealing with packaging waste issues. The average regression value on knowledge and awareness factors in younger age groups tended to be more positive. This can be interpreted as the younger age groups being more familiar with new knowledge and awareness approaches than the older age group.

The results of factor analysis suggest that with producer contribution, producers may consider involving Waste Banks, collection feedback, recyclability of their packaging products, and helping to organize their contribution. When contributing physically and financially, it is also important to consider the transparency of their activity to the public, knowledge level of the EPR concept and producer program, and involvement of Waste Bank in producer activity. Collecting feedback from Waste Banks can be the initial step to improve producer contribution in EPR. In the Waste Bank system, the voluntary waste segregation and collection activity may directly meet stakeholder responsibility for recycling by exchanging price information. The willingness or ability of the recycling party to accept collected segregated packaging waste may indicate that the existing recycling system has a limited capacity to accept the packaging waste collected.

The abovementioned information and findings from this study allow several points to be considered by producers. Since waste banks have an important role, producers can assist waste banks in collection and socialization efforts, which can also raise awareness at the consumer level. By considering product recyclability, producers can indirectly support separation efforts at the consumer level and recycling efforts at the post-consumer stage. Waste bank members also consider local government institutions as an important stakeholder; therefore, producers can also consider cooperation with local institutions. Producers can consider the type of material selected for the product packaging to fit the existing recycling system. Producers also may gather information regarding limitation of existing recycling methods to process the product packaging at the post-consumer stage. 
From the perspective of waste bank members, several points from other studies can be confirmed such as the importance of raising awareness of recycling benefits [9], provision of a convenient method for collection [21], and influence of knowledge and attitudes toward awareness [20]. In addition, to the results emphasize the expansion of producer roles at the post-consumer stage, including producer consideration, contribution, and collection cooperation. Compared to other studies, the results of this study were obtained from community-based approach and focused more on the producer contribution to reducing the environmental impact of waste management rather than waste management in general.

In addition to recent development, the Ministry of Environment and Forestry of Indonesia enacted a roadmap regulation of waste reduction by producers in 2019. Producers are expected to contribute to the 10-y reduction of waste generation until 2029 through reporting and campaigns to reduce waste generation [13].

However, this study has certain limitations. The selected factors analyzed in this study do not cover all questions asked. Therefore, the analysis and conclusion may be only applicable to the selected factors instead of all questions in the questionnaire. The scope of this study is also limited around Bandung municipality area and selected Waste Banks. The limited number of surveyed Waste Banks was because of accuracy limitations in obtaining Waste Bank information. Further studies that consider a wider geographical scope and increased number of waste banks are recommended to provide a more accurate policy recommendation.

\subsection{Policy Implication}

This study may provide areas for producers to consider developing their program to comply with recent developments in waste management regulation in Indonesia by considering alternative waste management through community waste banks. It is also recommended that there is a specific policy to support the improvement of the capability for specific collection for recycling purposes and to promote general knowledge of producer activities in reducing the environmental impact of packaging waste.

Producers may consider involving Waste Banks and collecting feedback from them. The collected feedback from Waste Banks may require producers to consider the recyclability of their packaging and how they organize the activity at post-consumer stage. By actively doing so, producers may contribute to improving public knowledge and awareness on their contribution in reducing the environmental impact of packaging waste.

\section{Conclusions}

In this study, feedback from waste bank members from two Waste Bank points around the Bandung municipality, Indonesia, was collected to determine the potential role of Waste Banks to promote the contribution of producers in the post-consumer stage. The analysis result suggests that several factors should be considered when promoting EPR policy, namely producer consideration, producer contribution, knowledge level, collection cooperation, and awareness of the importance of packaging waste issues. 
Producers can consider the identified factors when contributing to managing packaging waste issues and to comply with recent regulation changes.

\section{Declarations}

\section{Availability of data and materials}

The data will not be shared for the reason why the respondents agreed only for the survey.

\section{Competing interest}

The authors declare that there is no competing interest

\section{Funding}

The authors received no financial support for the research, authorship, and/or publication of this article.

\section{Authors' contributions}

Antonius Priyo Nugroho Sulami is responsible for the conception of the study, data collection, analysis, and drafting the manuscript, Takehiko Murayama provided guidance and advice for analysis and revisions, and Shigeo Nishikizawa provided guidance and advice for analysis and revisions. All authors read and approved the final manuscript.

\section{Acknowledgements}

The authors thank all relevant waste bank stakeholders and the survey team for their support during the commencement of this study.

\section{References}

1. Akenji, L, Hotta, Y, Bengtsson, M, \& Hayashi, S (2011) EPR policies for electronics in developing Asia: an adapted phase-in approach. Waste Management \& Research 29(9): 919-930.

2. BPS-Statistics of Bandung City (2015) Kota Bandung Dalam Angka 2015 (Bandung City in Figures 2015). Available

at: https://bandungkota.bps.go.id/publication/2016/02/01/fec567ef289826514c9a3417/kotabandung-dalam-angka-2015.html (accessed 28 December 2020).

3. Chaerul, M, Fahruroji, A R, \& Fujiwara, T (2014) Recycling of plastic packaging waste in Bandung City, Indonesia. Journal of Material Cycles and Waste Management 16(3): 509-518.

4. Damanhuri, E and Padmi, T (2012) The Role of Informal Collectors of Recyclable Waste and Used Goods in Indonesia. In: E. Damanhuri (eds) Post-Consumer Waste Recycling and Optimal Production. 
InTech,23-44.

5. Damanhuri, E, Wahyu, IM, Ramang, R, and Padmi, T (2009) Evaluation of municipal solid waste flow in the Bandung metropolitan area, Indonesia. Journal of Material Cycles and Waste Management 11(3): 270-276.

6. Government of Republic of Indonesia. Undang-Undang no.18 Tahun 2018 tentang Pengelolaan Sampah (Waste Management Act no.18 Year 2008). Jakarta: Government of Republic of Indonesia. [In Indonesian]

7. Government of Republic of Indonesia. Peraturan Pemerintah Nomor 81 Tahun 2012 Tentang Pengelolaan Sampah Rumah Tangga Dan Sampah Sejenis Sampah Rumah Tangga (Government Regulation No.81 Year 2012 regarding Management of domestic waste and similar waste). Jakarta: Government of Republic of Indonesia [In Indonesian]

8. Gupt, Y, \& Sahay, S (2015) Review of extended producer responsibility: A case study approach. Waste Management \& Research 33(7): 595-611.

9. Khan, F, Ahmed, W, \& Najmi, A (2019) Understanding consumers' behavior intentions towards dealing with the plastic waste: Perspective of a developing country. Resources, Conservation and Recycling, 142:49-58.

10. Kubota, R, Horita, M, \& Tasaki, T (2020) Integration of community-based waste bank programs with the municipal solid-waste-management policy in Makassar, Indonesia. Journal of Material Cycles and Waste Management 22(3): 928-937.

11. Leal Filho, W, Saari, U, Fedoruk, M, lital, A, Moora, H, Klöga, M, and Voronova, V (2019) An overview of the problems posed by plastic products and the role of extended producer responsibility in Europe. Journal of Cleaner Production 214: 550-558.

12. Marshall, R. E, and Farahbakhsh, K (2013) Systems approaches to integrated solid waste management in developing countries. Waste Management 33(4): 988-1003.

13. Ministry of Environment and Forestry of Republic of Indonesia (2019) Peraturan Menteri Lingkungan Hidup dan Kehutanan Republik Indonesia Nomor P.75/MENLHK/SETJEN/KUM.1/10/2019 tentang Peta Jalan Pengurangan Sampah Oleh Produsen (Ministry of Environment and Forestry Regulation No. P.75/MENLHK/SETJEN/KUM.1/10/2019 regarding Waste Reduction Roadmap by Producer). Jakarta: Ministry of Environment sand Forestry of Republic of Indonesia. [In Indonesian]

14. Ministry of Environment Republic of Indonesia. Peraturan Menteri no.13 tahun 2012 tentang Pedoman, Pelaksanaan Reduce, Reuse, dan Recycle melalui Bank Sampah (Ministry of Environment Regulation no.13 Year 2012 about Implementation Guideline of Reduce, Reuse, and Recycle through Waste Bank). Jakarta: Ministry of Environment Republic of Indonesia. [In Indonesian]

15. OECD (2016). Extended Producer Responsibility: Updated Guidance for Efficient Waste Management. Paris: OECD Publishing

16. Pariatamby, A and Tanaka, M (eds) Municipal Solid Waste Management in Asia and the Pacific Islands. Singapore: Springer Singapore. 
17. Putri, AR, Fujimori, T, \& Takaoka, M (2018) Plastic waste management in Jakarta, Indonesia: evaluation of material flow and recycling scheme. Journal of Material Cycles and Waste Management 20(4): 2140-2149.

18. Raharjo, S, Matsumoto, T, Ihsan, T, Rachman, I, and Gustin, L (2017) Community-based solid waste bank program for municipal solid waste management improvement in Indonesia: a case study of Padang city. Journal of Material Cycles and Waste Management 19(1): 201-212.

19. Sembiring, E and Nitivattananon, V (2010) Sustainable solid waste management toward an inclusive society: Integration of the informal sector. Resources, Conservation and Recycling, 54(11): 802-809.

20. Singhirunnusorn, W, Donlakorn, K, \& Kaewhanin, W (2012) Contextual Factors Influencing Household Recycling Behaviours: A Case of Waste Bank Project in Mahasarakham Municipality. Procedia Social and Behavioral Sciences 36(6): 688-697.

21. Stoeva, K and Alriksson, S (2017) Influence of recycling programmes on waste separation behaviour. Waste Management 68: 732-741.

22. Sulami, APN, Murayama, T and Nishikizawa, S (2017) Current Issues and Situation of Producer Responsibility in Waste Management in Indonesia. Environment and Natural Resources Journal, 16(1): 70-81.

23. Suttibak, $S$ and Nitivattananon, $V(2008)$ Assessment of factors influencing the performance of solid waste recycling programs. Resources, Conservation and Recycling 53(1-2): 45-56.

24. Tong, $X$, Tao, D, and Lifset, $R$ (2018) Varieties of business models for post-consumer recycling in China. Journal of Cleaner Production, 170: 665-673.

25. Waste4Change (2018) Open for collaboration: Packaging Waste Dropping Point Program [Blog Post]. Available at: http://waste4change.com/deposit-your-packaging-waste-at-our-praisedroppingbox/ (accessed 20 December 2018)

26. Wijayanti, DR, \& Suryani, S (2015) Waste Bank as Community-based Environmental Governance: A Lesson Learned from Surabaya. Procedia - Social and Behavioral Sciences 184: 171-179.

\section{Figures}



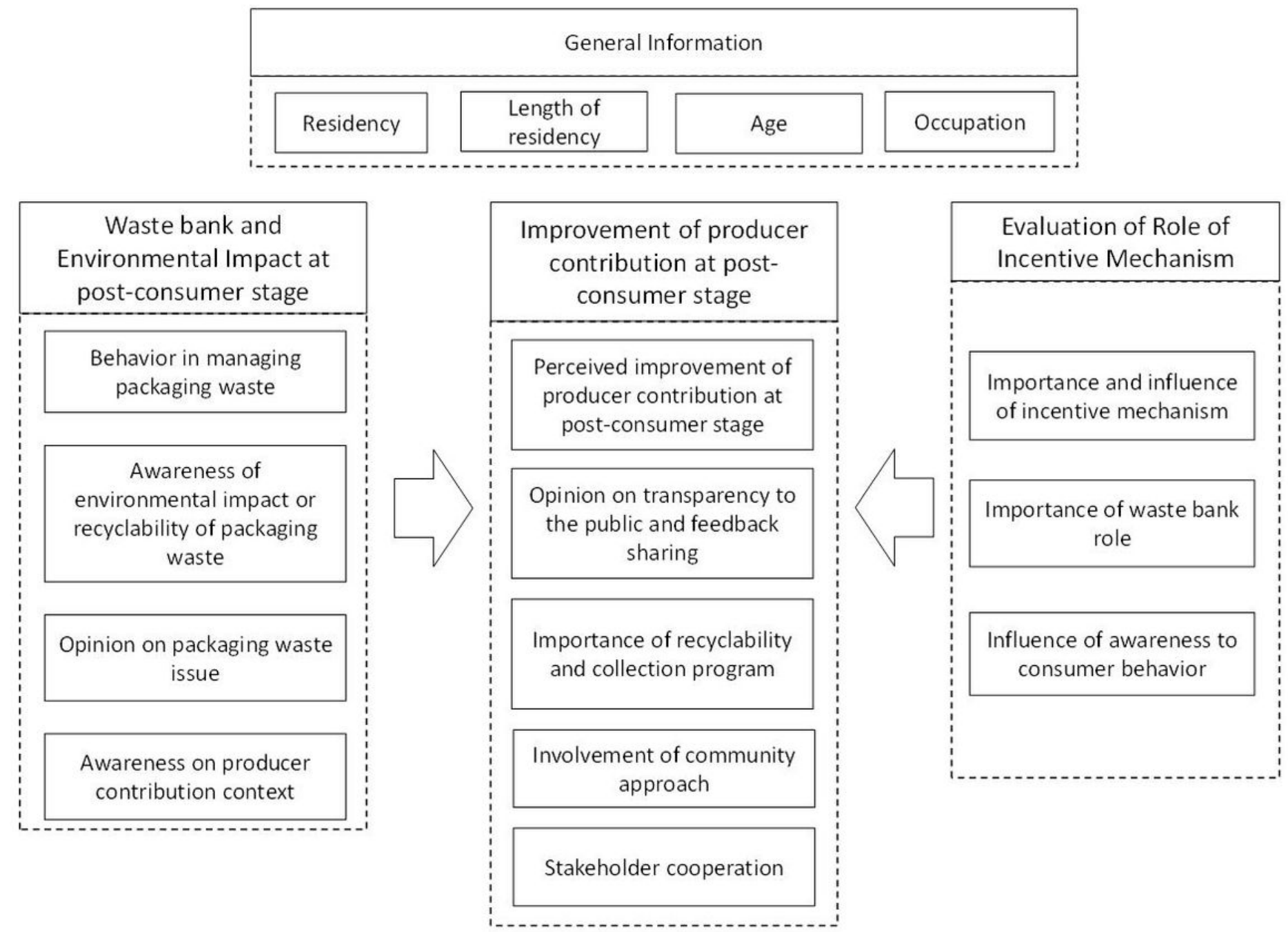

\section{Figure 1}

\section{Questionnaire Structure}




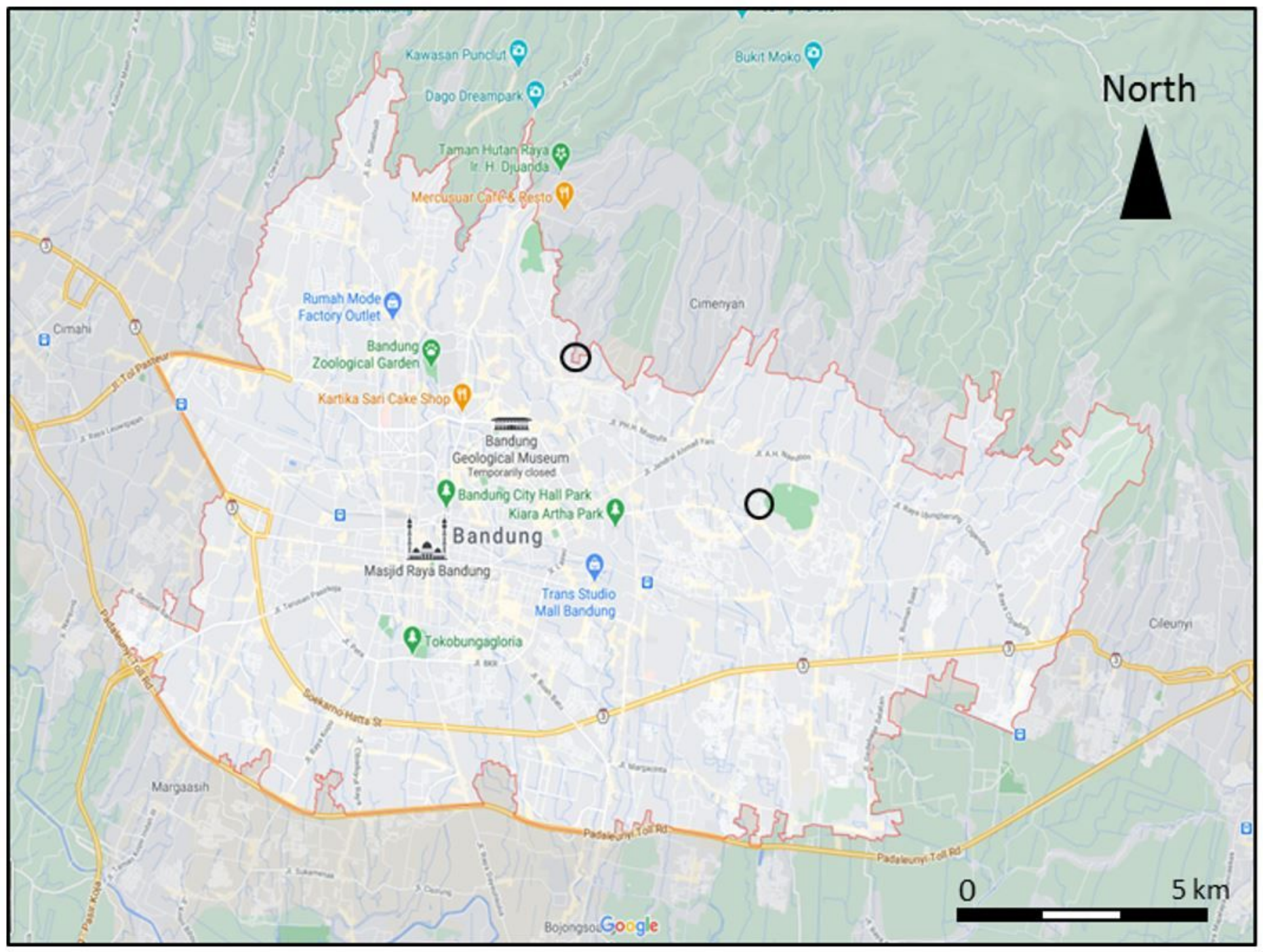

Figure 2

Location of Waste Bank Survey. Note: The designations employed and the presentation of the material on this map do not imply the expression of any opinion whatsoever on the part of Research Square concerning the legal status of any country, territory, city or area or of its authorities, or concerning the delimitation of its frontiers or boundaries. This map has been provided by the authors. 
very important $\square$ important $\square$ neutral $\square$ not so important $\square$ not important at all

Importance of incentive mechanism

$0 \%$

$20 \%$

$40 \%$

$60 \%$

$80 \%$

$100 \%$

Importance of waste bank role

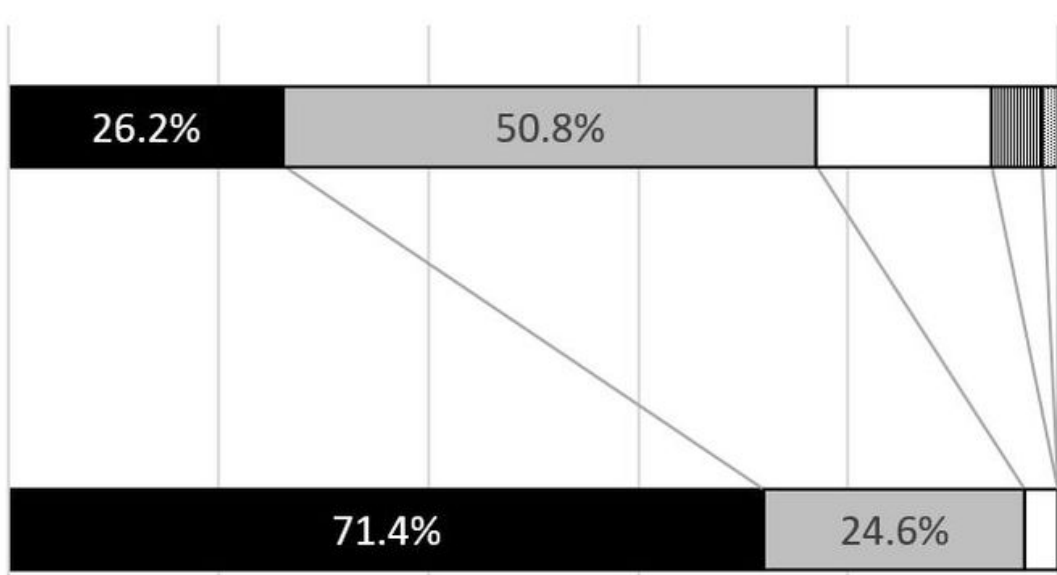

\section{Figure 3}

Perception on Incentive Mechanism and Waste bank role

\begin{tabular}{|c|c|}
\hline $\begin{array}{c}\text { Waste bank and } \\
\text { environmental impact at } \\
\text { post-consumer stage }\end{array}$ & $\begin{array}{c}\text { Improvement of producer } \\
\text { contribution at post } \\
\text { consumer stage }\end{array}$ \\
\hline
\end{tabular}

Evaluation of Role of Incentive Mechanism

\begin{tabular}{|c|l|l|l|}
\hline Q7 & Awareness & Q22 & Physical Contribution \\
\hline Q8 & Behavior & Q23 & Financial Contribution \\
\hline Q11 & Importance & Q24 & Organization Contribution \\
\hline Q12 & EPR Knowledge & Q26 & Recyclability consideration \\
\hline Q13 & Program Knowledge \\
\hline
\end{tabular}

\section{Figure 4}




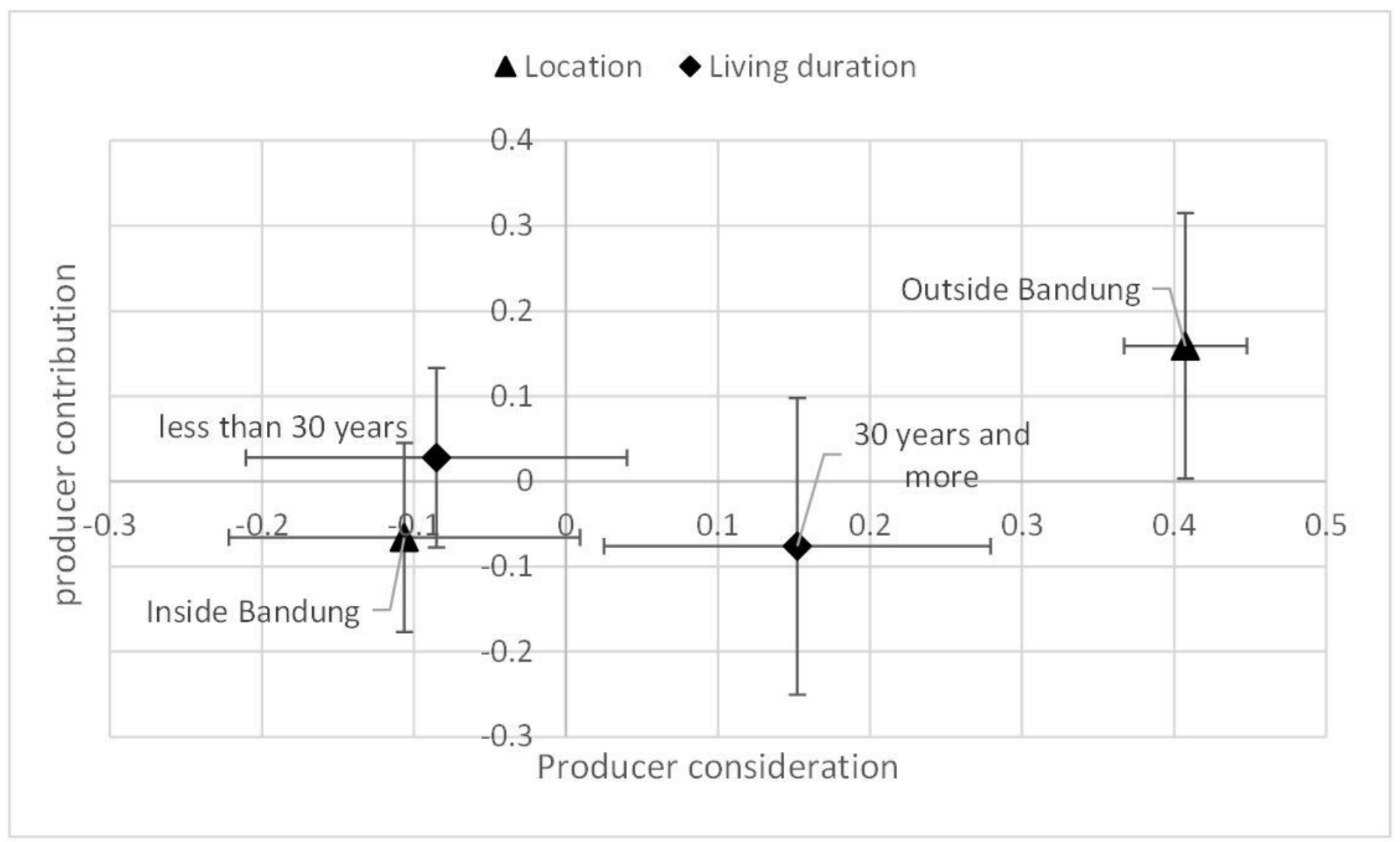

Figure 5

Producer Consideration vs Producer Contribution by location and living duration 


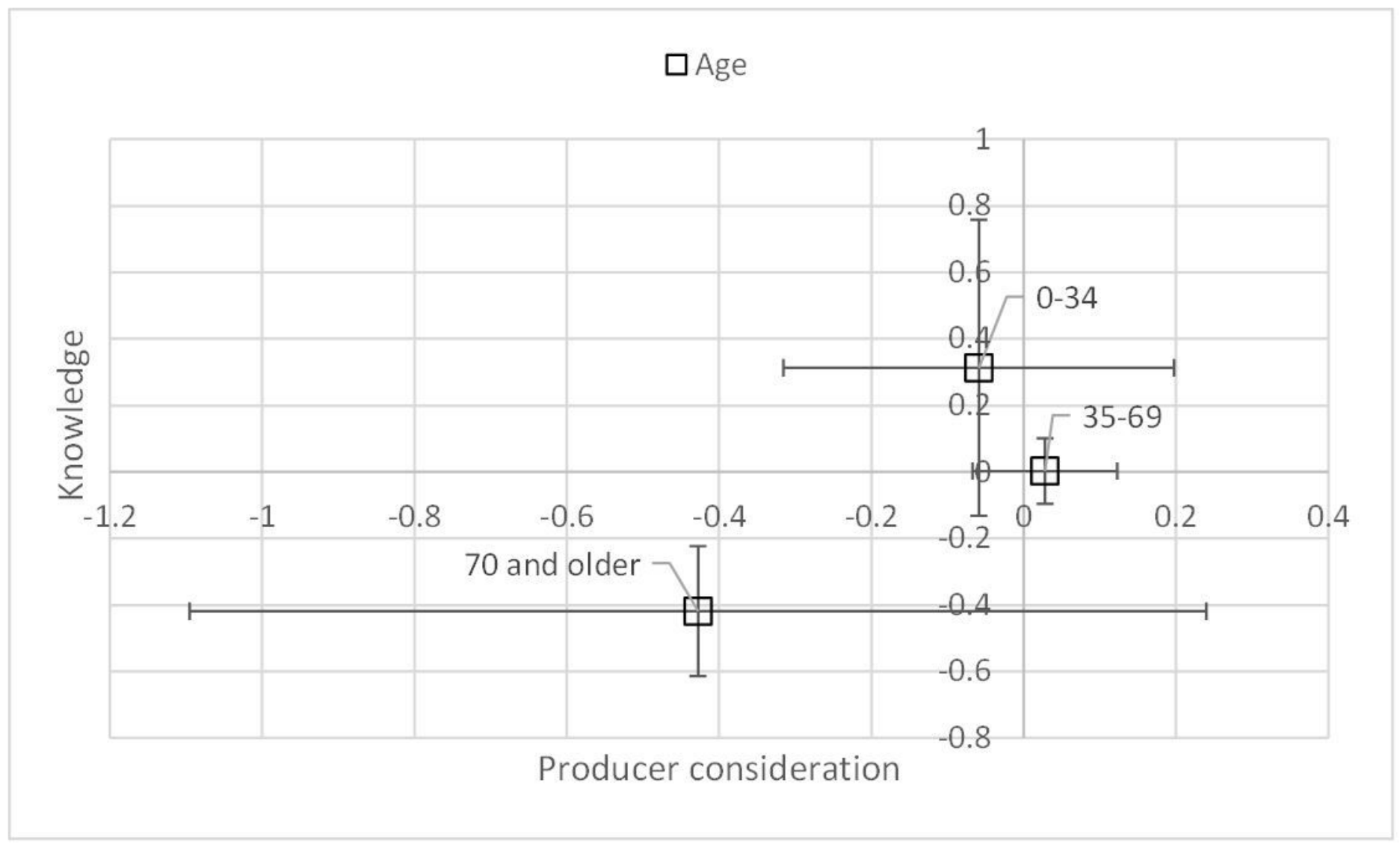

Figure 6

Producer Consideration vs Knowledge by Age 